\title{
Deconstructing networks of p53-mediated tumor suppression in vivo
}

\author{
Alyssa M Kaiser ${ }^{1}$ and Laura D Attardi ${ }^{*, 1,2}$
}

The transcription factor p53 is a vital tumor suppressor. Upon activation by diverse stresses including oncogene activation, DNA damage, hypoxia and nutrient deprivation, p53 activates a panoply of target genes and orchestrates numerous downstream responses that suppress tumorigenesis. Although early studies of p53 suggested that its ability to induce cell cycle arrest, senescence and apoptosis programs accounted for its tumor-suppressor activity, more recent studies have challenged this notion. Moreover, p53 regulates a suite of additional processes, such as metabolism, stem cell function, invasion and metastasis. The processes p53 coordinately regulates to enact tumor suppression, and how such regulation occurs, thus remain elusive. In this review, we will summarize our current knowledge of p53-mediated tumor-suppressive mechanisms gleaned from in vivo studies in mouse models.

Cell Death and Differentiation (2018) 25, 93-103; doi:10.1038/cdd.2017.171; published online 3 November 2017



Facts

- p53-mediated cell cycle arrest and apoptosis in response to acute DNA damage are dispensable for the suppression of diverse tumor types.

- Robust transactivation of the p53 target genes Cdkn1a, Puma and Noxa is not required for suppressing cancer in several mouse models.

- Non-canonical p53 functions, including regulating ferroptosis, metabolism, stem cell function and invasion, have been implicated in tumor suppression.

\section{Open Questions}

- Which p53 target genes are most important for mediating p53 tumor-suppressor function?

- Which are the critical cellular processes regulated by p53 during tumor suppression?
- What are the most relevant p53-activating stresses in incipient tumors in vivo?

- How does the stress and cell type affect which p53 responses are induced and contribute to tumor suppression?

\section{Using Mouse Genetics to Understand p53-Mediated Tumor Suppression}

The importance of tumor suppression by the p53 transcription factor is indisputable; over half of sporadic human cancers have mutations in the TP53 gene, and $>90 \%$ of Li-Fraumeni patients, who harbor a mutant allele of TP53, develop cancer in their lifetimes. ${ }^{1-3}$ The critical role of p53 in tumor suppression was unequivocally shown, however, by experiments performed in mouse models. Trp53 null mice develop cancer with complete penetrance in their first year of life. ${ }^{4,5}$ These mice overwhelmingly develop T-cell lymphomas, although sarcomas are also observed. Trp53 heterozygous mice are also predisposed to tumor development, but with longer latency than their Trp53 null counterparts, and they predominantly succumb to sarcomas, some lymphomas, and occasionally carcinomas. The increased cancer susceptibility of $\operatorname{Trp53} 3^{+/}$mice is reminiscent of those individuals with $\mathrm{Li}-$ Fraumeni syndrome who carry a mutant allele of TP53. ${ }^{3,6}$ In addition, Trp53 loss in numerous genetically engineered mouse models (GEMMs) for different cancer types accelerates tumor development. ${ }^{7-10}$ Together, these observations provide key in vivo experimental evidence of the importance of p53 in tumor suppression.

Since these original observations, mouse models have continued to be instrumental for understanding p53 tumor-

\footnotetext{
${ }^{1}$ Division of Radiation and Cancer Biology, Department of Radiation Oncology, Stanford University School of Medicine, Stanford, CA, USA and ${ }^{2}$ Department of Genetics, Stanford University School of Medicine, Stanford, CA, USA

${ }^{*}$ Corresponding author: LD Attardi, Division of Radiation and Cancer Biology, Department of Radiation Oncology, Stanford University School of Medicine, 269 Campus Drive, Stanford, CA 94305, USA. E-mail: attardi@stanford.edu

Received 06.6.17; revised 18.8.17; accepted 31.8.17; Edited by F Pentimalli; published online 03.11.17
} 


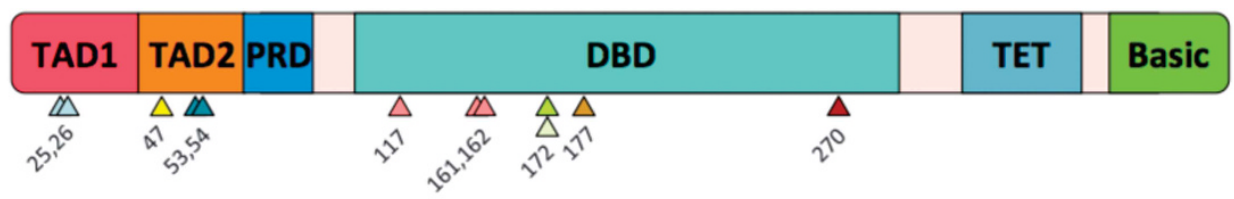

b

\begin{tabular}{|c|c|c|c|c|c|}
\hline Marker & Genotype & p53 mutation & p53 function & Phenotype & Reference \\
\hline & $\operatorname{Trp53}$ เ25ew26s & $\begin{array}{l}\text { Mutations that inactivate } \\
\text { TAD1 in reporter assays. }\end{array}$ & $\begin{array}{l}\text { - Deficient in transactivation of many target } \\
\text { genes, including classical targets such as } \\
\text { Cdkn1a, Puma, and Noxa. }\end{array}$ & $\begin{array}{l}\text { - p53-dependent apoptosis and cell cycle arrest in response to } \\
\text { acute DNA damage are abrogated. } \\
\text { - Suppresses lung adenocarcinoma, B-and T-cell lymphomas, } \\
\text { fibrosarcoma, and medulloblastoma in mice. } \\
\text { - Constitutive expression causes embryonic lethality. }\end{array}$ & $18,19,23$ \\
\hline & 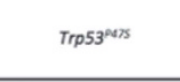 & $\begin{array}{l}\text { Single nucleotide } \\
\text { polymorphism in TAD2 seen } \\
\text { in some African populations. }\end{array}$ & $\begin{array}{l}\text { - Deficient in transactivation of a subset of } \\
\text { target genes, including G/s2, Noxa, and } \mathrm{Sco} 2 \text {. }\end{array}$ & $\begin{array}{l}\text { - Induction of ferroptosis in MEFs is reduced. } \\
\text { - Mice display an increased rate of spontaneous cancer. }\end{array}$ & 72 \\
\hline & 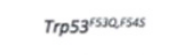 & $\begin{array}{l}\text { Mutations that inactivate } \\
\text { TAD2 in reporter assays. }\end{array}$ & $\begin{array}{l}\text { - Proficient in transactivation of classical p53 } \\
\text { target genes. }\end{array}$ & - No compromised phenotype compared to wild-type mice. & 18 \\
\hline & $\operatorname{Trp53}$ Lasaw265,53arsas & $\begin{array}{l}\text { Mutations that inactivate } \\
\text { each TAD in reporter assays. }\end{array}$ & $\begin{array}{l}\text { - Deficient in transactivation of all p53 target } \\
\text { genes. }\end{array}$ & $\begin{array}{l}\text { - Mice mirror the phenotypes of } \operatorname{Trp53}{ }^{\prime} \text { mice, including no tumor } \\
\text { suppressor activity. }\end{array}$ & 18,23 \\
\hline & 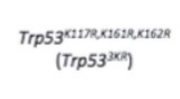 & $\begin{array}{l}\text { Lysine to arginine mutations } \\
\text { introduced block acetylation } \\
\text { of } 3 \text { residues in the DBD. }\end{array}$ & $\begin{array}{l}\text { - Deficient in transactivation of some genes, } \\
\text { such as Cdkn1a, Puma, Noxa, Bax, Pml, and } \\
\text { Pai1. }\end{array}$ & $\begin{array}{l}\text { - p53-dependent apoptosis and cell cycle arrest in response to } \\
\text { acute DNA damage are abrogated. } \\
\text { - Replicative and oncogene-induced senescence are impaired. } \\
\text { - Suppresses spontaneous tumor development in mice. }\end{array}$ & 65 \\
\hline & $\operatorname{Trp53^{21729}}$ & $\begin{array}{l}\text { Human tumor mutation in } \\
\text { the DBD. }\end{array}$ & $\begin{array}{l}\text { - Deficient in transactivation of apoptosis } \\
\text { genes such as Puma and Noxa. } \\
\text { - Proficient in activation of Cdkn1a. }\end{array}$ & $\begin{array}{l}\text { - p53-dependent apoptosis is abrogated. } \\
\text { - Cell cycle arrest and senescence responses are partially intact. } \\
\text { - Maintains genomic stability in cancer cells. } \\
\text { - Suppresses early onset T cell lymphomas but not other cancer } \\
\text { types in mice. }\end{array}$ & 42 \\
\hline & $\operatorname{Trp} 53^{a 272 w}$ & $\begin{array}{l}\text { "Hotspot" human tumor } \\
\text { mutation in the DBD. }\end{array}$ & $\begin{array}{l}\text { - Incapable of binding DNA (conformational } \\
\text { mutant). }\end{array}$ & - No tumor suppressor activity. & 16,17 \\
\hline & $\operatorname{Trp53^{(12me}}$ & $\begin{array}{l}\text { Human tumor mutation in } \\
\text { the DBD. }\end{array}$ & $\begin{array}{l}\text { - Cooperative DNA binding is compromised. } \\
\text { - Deficient in transactivation of apoptosis } \\
\text { genes such as Puma, Noxa, and Bax. } \\
\text { - Proficient in transactivation of some genes } \\
\text { such as Cdkn1a and Gls2. }\end{array}$ & $\begin{array}{l}\text { - p53-dependent apoptosis is abrogated. } \\
\text { - Cell cycle arrest and senescence responses are intact. } \\
\text { - Suppresses early onset T cell lymphomas but not other cancer } \\
\text { types in mice. }\end{array}$ & 43 \\
\hline & $\operatorname{Trp53^{2270\mathrm {H}}}$ & $\begin{array}{l}\text { "Hotspot" human tumor } \\
\text { mutation in the DBD. }\end{array}$ & - Incapable of binding DNA (contact mutant). & - No tumor suppressor activity. & 16 \\
\hline
\end{tabular}

Figure 1 p53 mutant mouse models. (a) Domain structure of p53. The arrowheads depict the location of mutations introduced into knock-in mouse models discussed in this review. PRD, proline-rich domain. Basic, basic amino-acid-rich region. (b) Descriptions of the mouse models with mutated forms of p53 discussed in this review

suppressor function. Although findings from cell culture models have defined p53 target genes, responses and signaling pathways, these models cannot directly address the contribution of these functions to tumor suppression per se, as these in vitro systems lack several key components that shape tumor behavior in vivo such as the 3D tissue architecture, the host immune system and the tumor microenvironment. To understand pathways and mechanisms of p53 action in vivo, numerous strains of mice harboring genetic alterations in Trp53, p53 regulators and p53 target genes have been generated and analyzed for tumor predisposition.,11 Collectively, these mouse model experiments have begun to reveal the mechanisms underlying p53 tumor-suppressor function.

\section{Transcriptional Activation Function is Critical for Tumor Suppression}

p53 is a transcription factor that can induce the expression of hundreds of target genes. In response to diverse stresses, including hyperproliferative signals, DNA damage, hypoxia and nutrient deprivation - all of which may be experienced by emerging cancer cells $-\mathrm{p} 53$ is activated by displacement from its negative regulators, Mdm2 and Mdm4. ${ }^{12-14}$ Activated p53 can bind to consensus sites in the genome and induce transcription of a host of target genes to ultimately impede tumorigenesis. $^{1,2}$ In addition, transactivation-independent functions have been ascribed to p53, including promoting apoptosis through mitochondrial membrane permeabilization and directly repressing transcription. ${ }^{15}$

To define molecular mechanisms of p53 action in tumor suppression, several Trp53 mutant knock-in mouse models were developed to interrogate the contribution of different p53 domains to cancer suppression (Figure 1). p53 has discrete domains critical for its function as a transcription factor (Figure 1a): ${ }^{1}$ two amino-terminal transactivation domains (TADs), a sequence-specific DNA-binding domain (DBD) and a tetramerization domain (TET). Over $80 \%$ of TP53 mutations found in human cancers are in the DBD, suggesting that p53 binding to and activating its transcriptional targets is essential for its tumor-suppressor function. ${ }^{3}$ Two of the most common sites of mutations in human cancers (termed 'hotspots') are in the DBD at codons 175 and 273 and prohibit p53 from binding DNA. ${ }^{3}$ Knock-in mice expressing Trp53 mutated at the equivalent murine residues $\left(\operatorname{Trp} 53^{R 172 H}\right.$ and $\operatorname{Trp53}{ }^{R 270 H}$, respectively) were generated to assess how these DBD mutations affect tumorigenesis. ${ }^{16,17} \operatorname{Trp53}{ }^{+/ M}$ mice ('M' designates either hotspot mutation) are just as susceptible to 
a

p53 activation in response to acute DNA damage

Activating signals

b

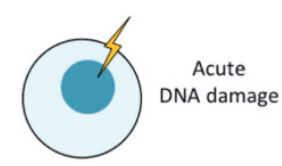

p53 activation during tumor development

Activating signals

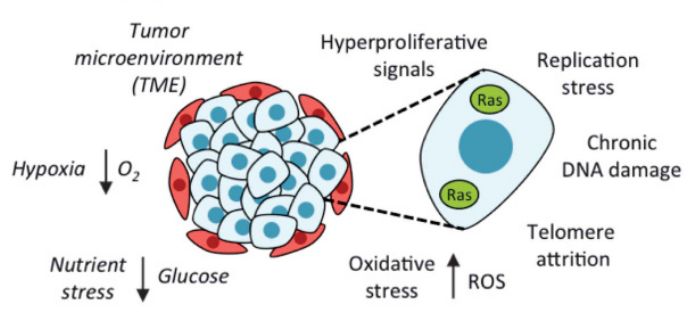

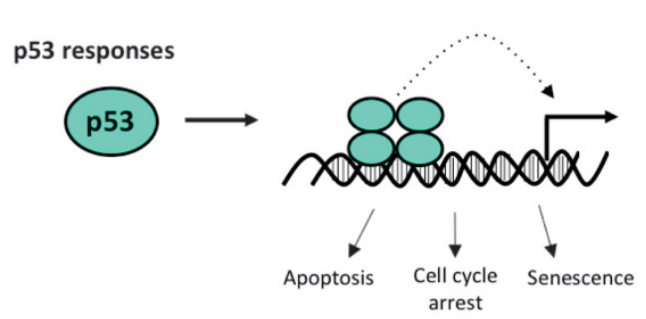

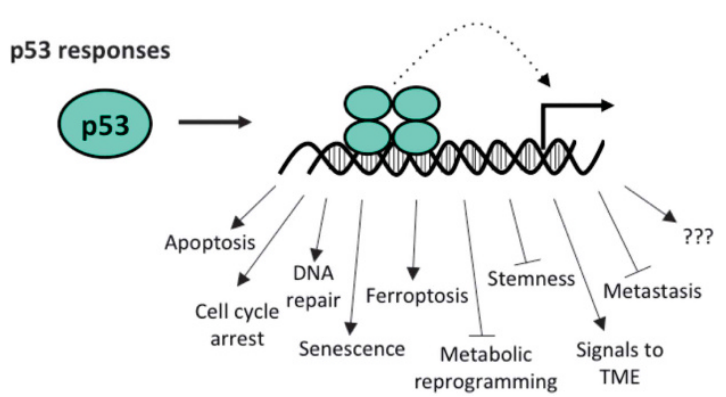

Figure 2 p53-activating stresses and responses. (a) The classical view of p53 can induce and response. In response to acute DNA damage, p53 can induce apoptosis, cell cycle arrest and senescence. These responses are dispensable for the suppression of numerous diverse tumor types. (b) A revised view of p53 activation and response during tumor development. A suite of stresses in the context of a developing tumor can activate p53. These stresses may be cell intrinsic or cell extrinsic. Cell-intrinsic stresses include hyperproliferative signals and chronic DNA damage arising from events such as replication stress, telomere attrition and oxidative stress. Cell-extrinsic stresses, denoted by italics, include signals from the tumor microenvironment (TME), such as poor oxygen and nutrient availability. In addition, p53 may be active in the 'basal' state to maintain homeostasis. Upon activation, p53 can function in numerous cellular pathways to oppose tumorigenesis. Which functions are activated by a given stress and contribute to tumor suppression is still under investigation

cancer as $\operatorname{Trp}^{+/-}$mice, indicating that the introduced mutations incapacitate 553 tumor-suppressor function. These mutant mouse models thus demonstrated that the ability of p53 to bind DNA is essential for tumor suppression.

The necessity of the p53 DBD for tumor suppression suggests that transactivation is also essential for this biological function. To directly assess the contribution of each TAD to tumor suppression, a panel of p53 TAD mutant mouse strains was created. ${ }^{18,19}$ Point mutations known to severely compromise TAD function in vitro were introduced into mice to create strains with mutations in TAD1 (Trp53 $3^{L 25 Q, W 26 S}$ ), TAD2 $\left(\operatorname{Trp53}^{F 53 Q, F 54 S}\right)$ or both TADs (Trp53 $\left.{ }^{\mathrm{L25Q}, \text { W26S, F53Q,F54S }}\right) .{ }^{20-22}$ Interestingly, mutating either TAD is not sufficient to compromise p53 tumor suppression, despite the fact that the


severely impaired in the transactivation of many p53 target genes, including Cdkn1a, Puma and Noxa. However, mutating both TADs renders the protein transcriptionally inert and unable to suppress tumorigenesis, demonstrating that p53 transactivation function is essential for tumor suppression. ${ }^{18,23}$

These mouse models have thus revealed the necessity of DNA binding and transactivation for effective tumor suppression. However, these findings do not address the downstream programs by which p53 suppresses cancer. Which responses and target genes are critical for tumor suppression? As we describe below, both knock-in mice with Trp53 mutations and p53 target gene knockout mice have helped to begin to delineate the contribution of specific p53 responses to its tumor-suppressor function (Figure 1b).

\section{'Classical' p53 Functions}

The earliest biological outcomes ascribed to p53 were the induction of cell cycle arrest, senescence and apoptosis, the so-called 'classical' p53 responses. p53 was initially discovered to block proliferation by inducing a transient $\mathrm{G} 1$ cell cycle arrest in response to acute DNA damage (Figure 2a), which could allow cells time to pause and resolve any sustained damage that could promote cancer development, a role known as 'guardian of the genome'. ${ }^{24-26}$ p53 can halt cell cycle progression in response to DNA damage by inducing transcription of Cdkn1a, which encodes the cyclindependent kinase inhibitor p21, although additional target genes such as Gadd45a can contribute to p53-mediated cell cycle arrest. ${ }^{27-31}$ In addition to inhibiting proliferation, p53 can induce apoptosis in response to DNA damage and hyperproliferative signals, ${ }^{32-34}$ a response envisioned to prevent tumorigenesis by removing damaged or inappropriately proliferating cells. p53 can trigger apoptosis through the direct induction of target genes, including pro-apoptotic Bcl-2 family members such as Bax, Puma and Noxa. ${ }^{35,36}$ As described below, multiple mouse models have helped to define the contribution of these classical responses to tumor suppression.

The role of cell cycle arrest/senescence in tumor suppression. The contribution of cell cycle arrest to tumor suppression was investigated initially using knockout mice lacking p53 target genes. Surprisingly, Cdkn1a $a^{-/-}$mice do not display early-onset tumorigenesis seen in $\operatorname{Trp}^{+/-}$and 
$\operatorname{Trp53}^{-/-}$mice, although a mild cancer susceptibility is observed beginning at 16 months, ${ }^{28,37}$ suggesting that p21 loss does not significantly compromise p53-mediated suppression of spontaneous tumors. Similarly, deletion of other p53 target genes that promote cell cycle arrest in vivo, including Gadd45a and Ptprv, does not enhance spontaneous tumorigenesis. ${ }^{29,31}$ However, loss of these cell cycle regulators can augment tumor development in specific contexts. For example, p21 deficiency cooperates with oncogenic Ras to promote mammary tumorigenesis ${ }^{38}$ and sarcoma formation, ${ }^{39}$ and Gadd45a loss accelerates Rasdriven mammary tumor formation. ${ }^{40,41}$ Although these studies demonstrate the importance of p53 target genes encoding cell cycle regulators in tumor suppression, they do not show that direct activation of these genes by p53 is necessary for tumor suppression.

Knock-in mouse strains expressing mutant p53 variants have also implicated cell cycle arrest in p53-mediated tumor suppression. One such strain - the $\operatorname{Trp5} 3^{R 172 P}$ strain (also known as Trp53515C) - harbors a human tumor-derived

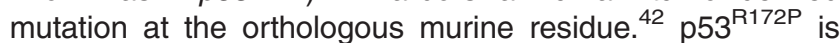
defective in mounting an apoptotic response to DNA damage and oncogene activation, but retains partial activity in irradiation-induced cell cycle arrest. Another model - the Trp53 ${ }^{E 177 R}$ mouse strain - similarly expresses a mouse analog of a human tumor-derived TP53 mutant that cannot induce apoptosis but can induce cell cycle arrest and some metabolic responses. ${ }^{43}$ Despite being compromised in apoptosis, $\mathrm{p} 53^{\mathrm{R} 172 \mathrm{P}}$ or $\mathrm{p} 53^{\mathrm{E} 177 \mathrm{R}}$ suffice to partially protect mice from early-onset lymphomas that characterize $\operatorname{Trp53}{ }^{-/}$mice, suggesting that cell cycle arrest contributes to suppressing early-onset spontaneous tumors. Indeed, Trp53 R172P/R172P, Cdkn1a ${ }^{-/}$mice display accelerated tumor onset compared with $\operatorname{Trp53} 3^{R 172 P / R 172 P}$ mice, ${ }^{44}$ suggesting that $\mathrm{p} 21$ and cell cycle arrest are important for tumor suppression in $\operatorname{Trp53}{ }^{R 172 P}$ mice.

Inducing a transient proliferative arrest can be beneficial if cells restore homeostasis and repair oncogenic lesions. However, at times cells may need to be permanently restrained, which p53 achieves by inducing senescence, an irreversible cell cycle arrest. p53 activates transcription of multiple genes involved in senescence, including Cdkn1a, PmI and Pai1. ${ }^{2}$ Several in vivo studies have correlated senescence and p53-mediated tumor suppression. For example, lategeneration $\mathrm{TerC}^{-/}$mice lack the RNA component of telomerase and exhibit telomere erosion and DNA damage signaling. ${ }^{45}$ These mice are cancer prone, and Trp53 deficiency accelerates cancer-associated mortality. $\operatorname{TerC}^{-/} ; \operatorname{Tr} 553^{R 172 P / R 172 P}$ and $\operatorname{TerC}^{-/} ; \operatorname{Trp}_{53^{+/+}}$mice are protected from tumor development to a similar extent, and tumor suppression is accompanied by senescence in vivo. ${ }^{46}$ Similarly, in B-cell lymphomas driven by the $E \mu-M y c$ transgene, tumor suppression by $\mathrm{p} 53^{\mathrm{R} 172 \mathrm{P}}$ is associated with the activation of cellular senescence markers. ${ }^{47}$ Wild-type p53 is associated with senescence in several tumor models, including murine models of non-small cell lung cancer and prostate cancer. ${ }^{48,49}$ For example, in a murine prostate cancer model, prostates in $\mathrm{Pten}^{-/}$mice display p53-dependent growth arrest and SA- $\beta$ gal positivity, whereas prostates in $\mathrm{Pten}^{-/} ; \mathrm{Trp}_{53}{ }^{-/}$mice are more proliferative and lack signs of senescence. ${ }^{50}$ These Pten ${ }^{-1-}$;
$\operatorname{Trp} 53^{-/-}$mice display a drastically reduced tumor latency, suggesting that p53-mediated senescence constrains tumor development.

Apoptosis contributes to tumor suppression. Initial evidence implicating the p53 apoptotic response in tumor suppression came from studies of oncogene-expressing fibroblast tumor xenografts and a choroid plexus epithelial tumor GEMM. ${ }^{51-53}$ In the latter model, highly apoptotic tumors arise after inactivation of retinoblastoma family proteins, and Trp53 inactivation diminishes tumor cell apoptosis and accelerates tumor growth. Moreover, deletion of the pro-apoptotic p53 target gene Bax accelerates tumor development, directly implicating apoptosis as a tumorsuppressive mechanism in this model. ${ }^{52}$ Similarly, in $E \mu$ Myc-driven B-cell lymphomas, p53 induces significant apoptosis. ${ }^{7}$ Genetically blocking apoptosis (i.e., through Bcl2 overexpression) mimics the phenotype of Trp53 loss in this model, suggesting that apoptosis is a primary mechanism by which p53 suppresses lymphomagenesis. ${ }^{54}$ In addition, loss of the p53 pro-apoptotic targets Bax, Puma, or Puma and Noxa, accelerates tumor development. ${ }^{35,55-57}$ However,

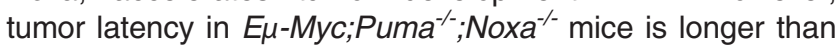
that in $E \mu-M y c ; p 53^{+/-}$mice, suggesting that p53 functions other than apoptosis contribute to tumor suppression in this model. ${ }^{35}$ Notably, the importance of p53-dependent apoptosis has not been well characterized in epithelial cancers, although loss of the p53 target gene Perp does compromise ultraviolet B-induced apoptosis and enhance UVB-induced skin carcinogenesis in mice. ${ }^{58}$ Again, an important consideration with experiments examining p53 target gene knockout mice is that p53-independent activation of these genes could contribute to tumor suppression. Nonetheless, these in vivo studies collectively suggest that p53-mediated apoptosis contributes to suppression of several tumor types.

\section{The Acute DNA Damage Response is Dispensable for Tumor Suppression}

The aforementioned studies implicated the p53 responses of cell cycle arrest, senescence, and apoptosis as essential for p53-mediated tumor suppression, and given the critical, wellestablished role of p53 downstream of acute DNA damage signals, it was envisioned that the p53 responses to acute genotoxic stress mediated its tumor-suppressor function (Figure 2a). This paradigm was strengthened by findings that the DNA damage response is engaged during incipient tumor development: nascent tumors frequently display markers of DNA damage signaling, including $\mathrm{\gamma H} 2 \mathrm{AX}, \mathrm{pCHK} 2$ and $\mathrm{pATM}$, and often express p53. ${ }^{59,60}$

This model has been overturned as multiple studies challenged the importance of p53 acute DNA damage responses for tumor suppression. The initial evidence came from mouse models where p53 activation was temporally regulated after DNA damage. In one model, mice expressing a tamoxifen-inducible p53-estrogen receptor fusion protein were used to study when p53 activity is required to suppress lymphomagenesis induced by ionizing radiation. ${ }^{61,62}$ Restoring p53 activity concurrently with irradiation induced widespread p53-dependent apoptosis, but this response offered no 
protection from cancer development compared with mice without p53 restoration. Interestingly, activating p53 8 days after irradiation did not induce any detectable apoptosis but extended lymphoma-free survival. In a separate study, Trp53 was deleted using a conditional allele before, concurrent with, or after whole-body irradiation ${ }^{63}$ Notably, the presence of p53 at the time of DNA damage offered no protection from tumorigenesis. Finally, mice deficient for $\mathrm{p} 19^{\text {Arf }}$, an upstream regulator of $\mathrm{p53}$, displayed accelerated development of DNA damage-induced fibrosarcomas, despite the fact that p53 responds normally to DNA damage in cells derived from $p 19^{A \text { if }}$ \% mice. ${ }^{64}$ These in vivo observations provided the first evidence that p53 responses to acute DNA damage are dispensable for the suppression of at least some cancers.

Further studies have extended this conclusion to a broad range of cancer types. As mentioned above, $p 53^{25,26}$ is severely compromised in the transactivation of many target genes, including canonical targets like Cdkn1a and Puma, which mediate cell cycle arrest and apoptosis. ${ }^{18,19}$ As a result, various cell types, including those of the thymus and small intestine, in $\operatorname{Trp53} 3^{25,26}$ mice fail to undergo apoptosis in response to $\gamma$-irradiation in vivo. Furthermore, p53 ${ }^{25,26} \mathrm{MEFs}$ cannot undergo cell cycle arrest when treated with DNAdamaging agents. However, p53 ${ }^{25,26}$ robustly suppresses various cancer types, including lung adenocarcinoma, medulloblastoma, fibrosarcoma, and T- and B-cell lymphomas. ${ }^{18,23}$ The studies of the $p 53^{25,26}$ mice elaborate the idea that $p 53$ acute DNA damage responses are dispensable for tumor suppression by demonstrating that they are expendable for the suppression of numerous, diverse tumor types arising from different tissues. In addition, studies of p53 25,26 have uncovered transcriptional programs important for tumor suppression. Although robust transactivation of canonical p53 targets is not required for tumor suppression, p53 25,26 activates transcription of a set of primarily novel p53 target genes. Further characterization of these genes will help to elucidate the transcriptional programs required for tumor suppression.

Support for the conclusions derived from studies of the $\mathrm{p} 53^{25,26}$ mice came from knock-in mice expressing $\mathrm{p} 53^{3 \mathrm{KR}}$, in which lysines 117,161 and 162 were mutated to arginine to block acetylation. ${ }^{65}$ These mutations disrupt the ability of p53 to induce select target genes, including Cdkn1a and Puma, and as a consequence, $\mathrm{p5} 3^{3 \mathrm{KR}}$ cannot induce cell cycle arrest or apoptosis in MEFs and thymocytes, respectively, in response to irradiation. In addition, senescence is impaired in $\mathrm{p5}^{3 \mathrm{~K} R}$-expressing MEFs. However, p53 ${ }^{3 \mathrm{KR}}$ can still transactivate some metabolic targets like Tigar and Gls2 and suppress both spontaneous tumor formation and pro-B-cell lymphomas in $\mathrm{Xrcc4}^{-/}$mice, furthering the notion that p53 responses to DNA damage are not essential for tumor suppression. ${ }^{66}$

Although studies of $p 53^{25,26}$ and $p 53^{3 K R}$ suggest that potent transcriptional activation of the canonical target genes Cdkn1a, Puma and Noxa is dispensable for p53-mediated tumor suppression, residual activation of these genes by these mutants could be contributing to suppressing cancer development. To investigate this possibility, Cdkn1a ${ }^{-/-} ; P_{\text {Pma }}{ }^{-/-}$; $\mathrm{Noxa}^{-/-}$mice were generated. ${ }^{67}$ Similar to cells derived from $\mathrm{p} 53^{25,26}$ and $\mathrm{p} 53^{3 \mathrm{KR}}$ mice, thymocytes from this triple knockout strain were deficient in p53-dependent apoptosis triggered by DNA-damaging agents. In addition, T lymphocytes did not arrest in G1, and dermal fibroblasts displayed impaired senescence after DNA-damaging agent treatment. Cdkn1a $^{-/-} ;$Puma $^{-/-} ;$Noxa $^{-/-}$mice were not predisposed to spontaneous tumor development, supporting the idea that these three major mediators of the p53 acute DNA damage response are not required for p53-dependent suppression of spontaneous tumorigenesis. Puma and Noxa are, however, required for robust suppression of $E \mu-M y c$ lymphomas, suggesting that the mechanisms of p53-mediated tumor suppression are context dependent. ${ }^{35}$

Together, these mouse models demonstrate that canonical p53 target genes and responses downstream of acute DNA damage are dispensable for tumor suppression. Yet these studies beg more questions than they answer. How do we reconcile prior data showing the importance of cell cycle arrest, senescence and apoptosis for tumor suppression with the data just described?

\section{Reconciling Old and New Studies}

Although studies of $\operatorname{Trp5} 3^{25,26}, \operatorname{Trp} 53^{3 K R}$, and $C d k n 1 a^{-/-}$; Puma $^{-/-} ; \mathrm{Noxa}^{-/-}$mice have revealed that $\mathrm{p} 53$ responses to acute DNA damage are dispensable for tumor suppression, we should not conclude that cell cycle arrest and apoptosis are unimportant to tumor suppression. Rather, these studies suggest that the p53 pathways mapped by studying acute DNA damage responses are dispensable for tumor suppression. Indeed, it seems logical that p53 is engaged by stresses other than acute DNA damage in the context of tumor suppression, such as oncogene activation, nutrient and oxygen deprivation, and chronic, low-level DNA damage (Figure 2b). ${ }^{2,12,13}$ Supporting the notion that apoptosis triggered by non-genotoxic stresses could be relevant for tumor suppression is the observation that the tumor suppression-competent $\mathrm{p} 53^{25,26}$ mutant can induce apoptosis in response to hypoxia and serum starvation. ${ }^{19}$ In addition, the cellular response to chronic DNA damage is mechanistically distinct from that to acute DNA damage, and therefore the response of p53 to chronic DNA damage may be relevant for tumor suppression. ${ }^{68}$ It is thus plausible that cell cycle arrest and/or apoptosis triggered by the diverse stresses present in incipient tumors could account for p53 tumor-suppressor function, via downstream pathways distinct from those involved in acute DNA damage responses. Alternatively, DNA damage responses could appear dispensable for p53mediated tumor suppression because compensatory

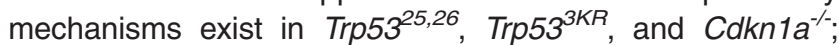
Puma $^{-/-} ;$Noxa $^{-/-}$mice that allow for tumor suppression.

Although these three mouse models have not proven that cell cycle arrest and apoptosis as a whole are dispensable for tumor suppression, they have prompted the exploration of alternative transcriptional programs and cellular processes that could mediate tumor suppression downstream of p53, which we will describe next (Figure 3). 


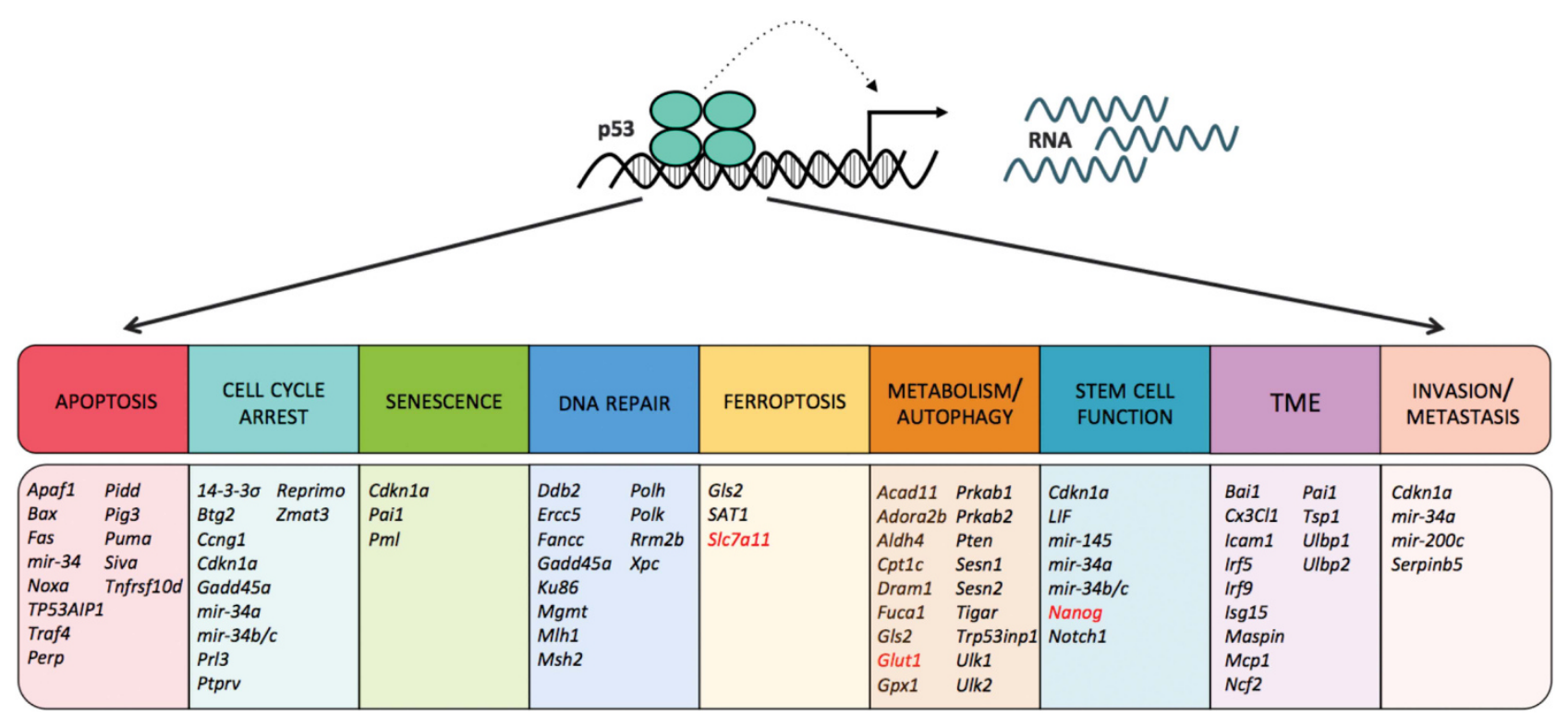

Figure 3 p53 suppresses cancer development through transcriptional regulation of target genes that regulate diverse cellular processes. p53 has been proposed to regulate a plethora of functions including apoptosis, cell cycle arrest, senescence, DNA repair, ferroptosis, metabolism, autophagy, stem cell function, invasion and metastasis. In addition, p53 is proposed to have non-cell autonomous functions that allow communication within the tumor microenvironemt (TME). Multiple target genes have been implicated in each response, and those that are activated by $p 53$ are indicated in black. Of note, p53 has also been suggested to act as a transcriptional repressor. Select genes to which p53 binds and represses transcription are indicated in red. The murine gene annotation is shown unless the gene has no mouse ortholog

\section{Emerging p53 Functions}

Ferroptosis as a new mechanism of tumor suppression. A recent function ascribed to $\mathrm{p} 53$ is the regulation of ferroptosis, an iron-dependent, non-apoptotic form of cell death. ${ }^{69}$ Ferroptosis is triggered by the inhibition of cystine uptake, which depletes glutathione levels and leads to the iron-dependent accumulation of reactive oxygen species (ROS) that trigger cell death. ${ }^{70}$ The first study to suggest that p53 regulates ferroptosis showed that p53 directly represses transcription of SLC7A11, a component of the cystine/glutamate transporter whose downregulation reduces cystine uptake and primes cells for ferroptosis. ${ }^{71}$ p53 has since been reported to activate the expression of genes involved in ferroptosis, including Gls2 and SAT1 ${ }^{72,73}$ Notably, although deficient for some p53 functions, the tumor suppression-competent $\mathrm{p} 53^{3 \mathrm{KR}}$ mutant retains the ability to repress SLC7A11 and to induce ferroptosis. ${ }^{71}$ Mutating a fourth acetylation site in $p 53$ lysine 98 to create a p53 ${ }^{4 K R}$ mutant abolishes SLC7A11 repression, ferroptosis, and tumor suppression in a xenograft model ${ }^{74}$ further correlating ferroptosis with p53-mediated tumor suppression. SLC7A11 overexpression enhances the growth of xenograft tumors expressing $p 53^{3 \mathrm{KR}}$, but not $p 53$-null tumors, suggesting that ferroptosis could be important for tumor suppression. An additional correlation between ferroptosis and tumor suppression came from knock-in mice expressing $\mathrm{p} 53^{\mathrm{P} 47 \mathrm{~S}}$, a TP53 polymorphic variant enriched in African and African-American populations. ${ }^{72}$ p53 $3^{\mathrm{P} 47 \mathrm{~S}}$ is impaired in regulating select p53 target genes, including the ferroptosis genes SLC7A11 and Gls2, and in triggering ferroptosis. Trp $53^{P 47 S}$ mice are susceptible to spontaneous tumorigenesis, again linking defective ferroptosis and tumorigenesis. However, the finding that p53 induces ferroptosis, and that this activity contributes to tumor suppression, is challenged by a recent study which suggests that p53 antagonizes ferroptosis in colorectal cancer cell lines. ${ }^{75}$ It will be interesting to assess how context affects p53 regulation of ferroptosis and to extend these studies to various GEMMs.

p53 regulates stemness. Another emerging function of p53 is in regulating stem cell function and differentiation. Initial observations suggested a potential role for p53 in embryonic stem cells, where p53 promotes differentiation after DNA damage by directly suppressing Nanog expression. ${ }^{76}$ The importance of p53 in inhibiting 'stemness' was bolstered by the discovery that p53 suppresses reprogramming of somatic cells into induced pluripotent stem cells. ${ }^{77-81}$ p53 promotes maintenance of the differentiated state at least in part by inducing Cdkn1a and subsequent cell cycle arrest. In addition, by inducing transcription of the microRNA miR-34a, p53 can indirectly repress pluripotency genes such as Nanog to restrain somatic cell reprogramming. ${ }^{82}$ These studies helped to establish the general paradigm that p53 opposes stemness and promotes differentiation. These functions could contribute to tumor suppression by promoting a more differentiated, less plastic phenotype in incipient cancer cells or by limiting the proliferation of cancer stem cells.

A role for $p 53$ in regulating cancer stem cells could reflect a physiological role in maintaining normal stem cell homeostasis to limit the inappropriate expansion of these cell populations. Indeed, the importance of p53 for stem cell homeostasis in vivo was shown by studies in which Trp53 loss promoted the expansion and blocked the differentiation of stem cell populations. For example, p53 limits the expansion of hematopoietic stem cells (HSCs), as Trp53\% mice have approximately two- to threefold more HSCs than wild-type 
mice. ${ }^{83}$ In addition, the mammary epithelium of $\operatorname{Trp} 53^{-/}$null mice displays increased numbers of mammary stem cells. ${ }^{84}$ Finally, Trp53 loss in the airway epithelium promotes the expansion of club cell populations and dampens differentiation into ciliated cells. ${ }^{85}$ Similarly, p53 limits the proliferation and promotes the differentiation of cancer stem cells. Trp53 inactivation in a mouse model of acute myeloid leukemia promotes expansion of leukemia-initiating myeloid progenitor cells. ${ }^{86}$ In addition, analysis of murine glioblastomas driven by Trp53 and Pten inactivation suggests that these tumor suppressors cooperate to restrict neural stem cell selfrenewal and promote differentiation. ${ }^{87}$ Future in vivo investigations will reveal how p53 regulates both normal and cancer stem cell function and how this activity contributes to tumor suppression.

p53 controls diverse aspects of metabolism. To fuel their enhanced growth and proliferation, neoplastic cells undergo metabolic reprogramming, typically by enhancing glycolytic function and dampening oxidative phosphorylation. ${ }^{88}$ Although the role of p53 in metabolism is complex, p53 is thought to oppose this reprogramming. p53 limits glycolysis and enhances oxidative phosphorylation through mechanisms such as restricting glucose uptake by Glut1 repression and modulating key TCA cycle enzymes via transactivation of genes like Sco2.

How does this transcriptional response contribute to tumor suppression in vivo? Interestingly, in several mouse models, transactivation of metabolic targets correlates with tumor suppression. In $\operatorname{Trp} 53^{3 K R}$ mice, where suppression of spontaneous tumors is intact, p53 induction of certain metabolic target genes like Tigar is preserved. ${ }^{65}$ In models where transactivation of metabolic targets like Gls2 is compromised, such as $\operatorname{Trp53} 3^{P 45}$ mice and p53 ${ }^{4 K R}$-expressing cells, p53mediated tumor suppression is defective. ${ }^{72,74}$ These observations establish a correlation between the activation of some p53 metabolic target genes and tumor suppression. However, direct evidence that these genes contribute to tumor suppression is lacking, and in some cases is contradictory. For example, Tigar $^{-/}$mice display less intestinal adenoma burden than Tigar $^{+/+}$mice. ${ }^{89}$ Furthermore, p53 targets such as Cpt1C and Acad11 promote tumor cell survival under metabolic stress. ${ }^{90,91}$ Perhaps individual target gene ablation does not mimic its deregulation in cancer; alterations in multiple targets may be required to compromise tumor suppression. It is also possible that regulation of some metabolic genes by p53 may be most important in untransformed cells and serve to maintain homeostasis.

In addition to altering patterns of fuel metabolism, cancer cells experience an increase in ROS, which can promote protumorigenic events such as proliferation. ${ }^{92}$ p53 exerts antioxidative effects by driving expression of target genes including Sesn1, Gls2 and Trp53inp1. ${ }^{2}$ Interestingly, loss of Trp53inp1, which encodes a nuclear protein that promotes an antioxidant response, accelerates spontaneous tumor development in $\operatorname{Trp53} 3^{+/-}$mice and pancreatic cancer in a Kras ${ }^{G 12 D_{-}}$ driven GEMM. ${ }^{93,94}$ Although the contribution of other antioxidant target genes to p53-mediated tumor suppression has not been rigorously tested in vivo, the importance of the antioxidant response as a whole has been demonstrated.
Treating $\operatorname{Trp}_{53^{-/}}$mice with the antioxidant $\mathrm{N}$-acetylcysteine significantly delayed spontaneous lymphoma development. ${ }^{95}$ These data suggest that the p53 antioxidant response contributes to tumor suppression. However, as with p53 regulation of fuel metabolism, the contribution of the p53 antioxidant response to tumor suppression is complex. For instance, p53 preserves antioxidant capacity and thus promotes viability in cancer cell lines experiencing serine deprivation. ${ }^{88}$ However, this response could potentially promote homeostasis and prevent incipient tumor development in noncancerous cells.

Another process critical for metabolic homeostasis is autophagy, a cellular process through which cytoplasmic components are degraded in the lysosome. ${ }^{96}$ By eliminating damaged proteins and organelles, autophagy promotes cellular integrity and survival, as well as mobilizing energy during nutrient deprivation. p53 can induce autophagy through transcriptional activation of genes such as Ulk1, Ulk2 and various Atg genes. ${ }^{97}$ Studies in oncogene-expressing fibroblasts demonstrated that loss of autophagy promotes transformation, and autophagy deficiency in lung and pancreatic tumors enhances tumor initiation, suggesting that autophagy may be tumor suppressive. ${ }^{97-100}$ However, the role of autophagy in cancer is complex, as it can also promote tumor progression. ${ }^{96}$ Thus, further studies are needed to fully understand how p53-activated autophagy impacts tumor development.

p53 maintains genomic integrity. By inducing a temporary G1 arrest upon DNA damage, p53 allots cells time to repair potentially oncogenic mutations in their genomes. ${ }^{2}$ p53 can additionally directly stimulate DNA repair, including base excision repair, nucleotide excision repair, and mismatch repair, to maintain genomic integrity. Several p53 target genes, including Ddb2, Gadd45a, MIh1 and Xpc, encode proteins that participate in DNA repair. Mouse strains lacking such genes, including $X p c^{-/}$, Gadd $45 a^{--}$and $D d b 2^{-/}$mice, are tumor-prone, suggesting that activation of DNA repair pathways could contribute to p53-mediated tumor suppression. ${ }^{40,41,101,102-104}$ Additional support for a role of DNA repair in tumor suppression comes from $\mathrm{Cdkn1a}^{-/-}$; Puma $^{-/-}$;Noxa ${ }^{-/-}$mice. ${ }^{67}$ Fibroblasts from these mice rapidly resolve DNA damage after irradiation, similarly to wild-type fibroblasts but unlike $\operatorname{Trp}_{53}{ }^{--}$fibroblasts, thus correlating intact DNA repair with p53-mediated tumor suppression.

p53 may also have a role in maintaining genomic stability at the chromosomal level. Abnormalities in chromosome number and structure are hallmarks of cancer, and the loss of Trp53 permits propagation of polyploid and aneuploid cells. ${ }^{105,106}$ Whether this instability observed in the absence of p53 is a cause or consequence of malignant progression is debated, and only correlative data are available from mouse models.

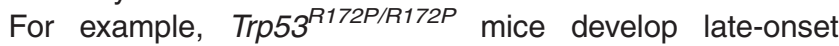
tumors that are typically diploid or tetraploid, whereas $\mathrm{Trp} \mathrm{3}^{-/}$mice develop tumors that are almost exclusively aneuploid. $^{42}$ In addition, spontaneous T-cell lymphomas arising in $\operatorname{Trp}^{-1-}$ mice display numerous copy number alterations in putative driver mutant alleles. ${ }^{107}$ Overall, data from mouse models suggest that intact p53 correlates with 
enhanced genomic integrity, but the contribution of this response to tumor suppression warrants further investigation.

p53 opposes invasion and metastasis in cancer. p53 is proposed to impede malignant progression by inhibiting tumor cell invasion and metastasis. ${ }^{108}$ In vitro, p53 restricts the motility and invasiveness of diverse primary and cancer cell types. In addition, p53 opposes epithelial-tomesenchymal (EMT), which is associated with the dissolution of cell-cell adhesion complexes and metastasis. In human cancer cell lines, p53 can indirectly downregulate key EMT transcription factors such as Snail1, Slug and Zeb1 by inducing their negative regulators. ${ }^{109-111}$

Despite this in vitro evidence, understanding how p53 loss contributes to invasion and metastasis in vivo has proven challenging. Sarcomas and carcinomas that arise in $\operatorname{Trp}_{53}{ }^{-1}$ and $\operatorname{Trp} 53^{+/-}$mice rarely metastasize, suggesting that Trp53 loss alone is not sufficient to induce metastasis. Supporting this conclusion are data from a $K_{r a s}{ }^{G 12 D}$-driven lung adenocarcinoma GEMM: although Trp53 deletion promotes tumor cell dissemination and metastasis, only some mice display these phenotypes, suggesting that Trp53 loss is not sufficient to initiate dissemination and metastasis but rather allows for stochastic events to initiate metastasis. ${ }^{9,112}$ Ultimately, it will be important to understand how the effects of p53 loss on cell motility and invasion in vitro contribute to metastasis in vivo.

Non-cell autonomous functions of p53. Beyond cell autonomous functions, p53 can stimulate an antitumorigenic microenvironment through non-cell autonomous mechanisms. For example, p53 can oppose angiogenesis by transactivating Tsp1, which encodes a secreted angiogenesis inhibitor. ${ }^{113}$ Moreover, p53 can affect the immune response by triggering expression of genes involved in immune cell recruitment and surveillance. p53 reactivation in liver carcinomas elicits transcription of inflammatory cytokines such as Csf1 and $/ / 15$, which promote recruitment of macrophages, neutrophils and natural killer cells and ultimately tumor clearance. ${ }^{114}$ p53 also promotes an antitumor microenvironment in hepatocellular carcinoma by inducing senescence of hepatic stellate cells, which subsequently release factors that trigger an antitumorigenic, M1 macrophage phenotype that enhances tumor cell clearance. ${ }^{115}$ p53-deficient hepatic stellate cells, meanwhile, skew macrophages to a tumor-promoting M2 phenotype. Finally, p53 also induces DD1a to promote macrophagemediated clearance of apoptotic cells, thereby limiting inflammation in the tumor microenvironment. ${ }^{116}$

p53 activation in the tumor stroma can also engage tumorsuppressive responses. TP53 mutations are frequently detected in the stroma of human tumors, suggesting that a selective pressure to inactivate TP53 in stromal cells exists. ${ }^{117,118}$ Indeed, inactivating the retinoblastoma family of tumor suppressors in the murine prostate epithelium triggers a paracrine p53-mediated proliferative arrest in the surrounding stromal fibroblasts and selects for Trp53 mutations. ${ }^{119}$ The advantage of p53 deficiency in the stroma is illustrated by experiments in which MCF7 breast cancer cells generate tumors at a faster rate after injection into $\operatorname{Trp53} 3^{-/}$mice than in $\operatorname{Trp} 3^{+/+}$mice. ${ }^{120}$ These data argue the importance of non-cell autonomous functions of p53 in suppressing tumor development.

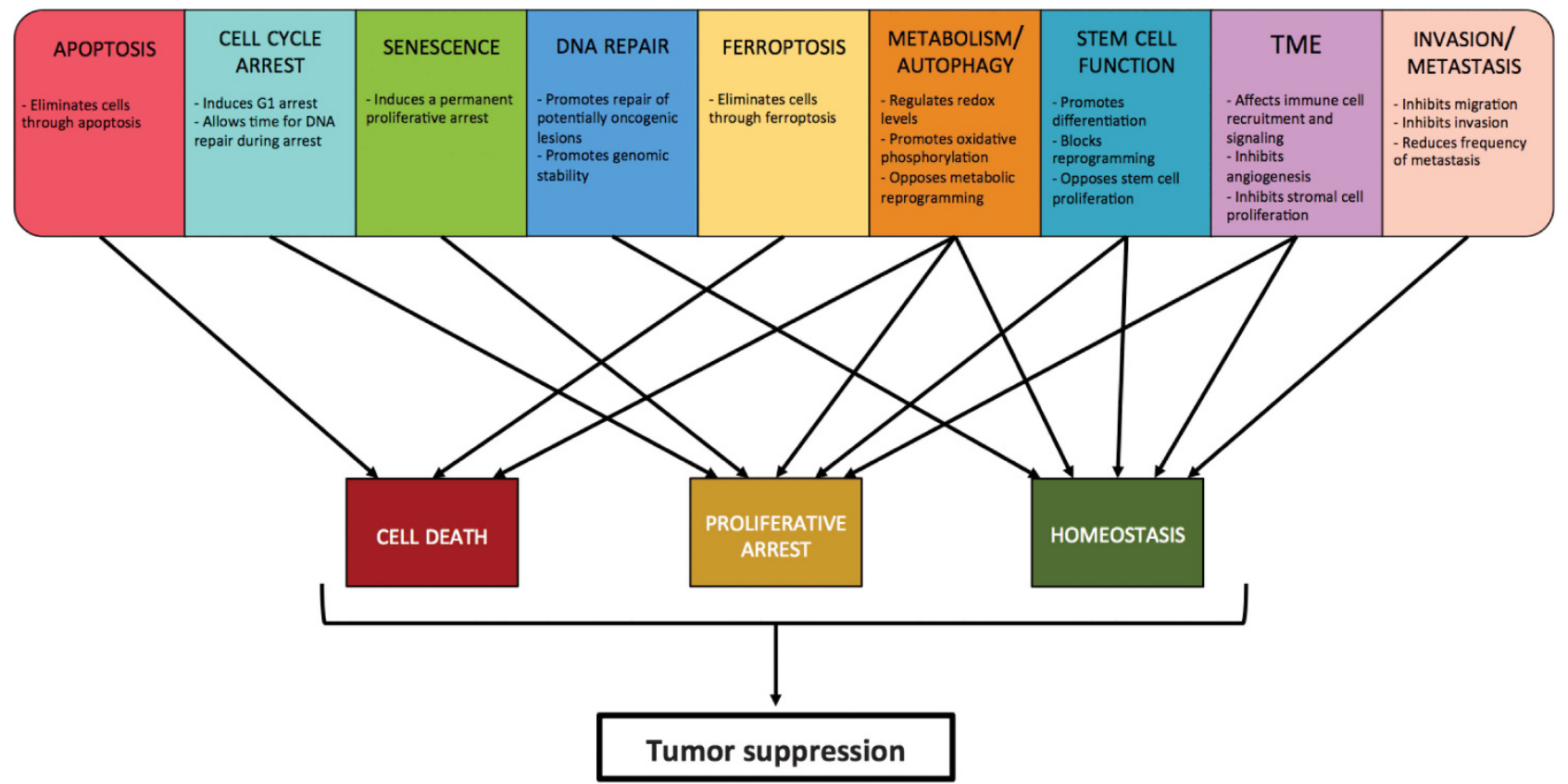

Figure 4 Diverse p53-regulated processes lead to common outcomes. Although p53 regulates many cellular processes (top), they all likely impinge upon the common outcomes of limiting cellular proliferation, through effects on both cell survival and cell division, and maintaining homeostasis. Regulating proliferation and promoting cellular homeostasis can lead to tumor suppression. Multiple p53 functions can potentially contribute to each of these tumor-suppressive outcomes, as indicated by arrows 


\section{Reconstructing p53-mediated tumor suppression}

In its capacity as a tumor suppressor, p53 must inhibit the propagation of cells with cancer-promoting alterations. Thus, the ability of p53 to impede proliferation by directly inducing cell cycle arrest and promoting cell death provides clear mechanisms by which it could suppress tumorigenesis. Indeed, numerous in vivo studies have unequivocally shown that abrogating p53-mediated cell cycle arrest or apoptosis in specific tumor models accelerates tumorigenesis. However, we now appreciate that p53 regulates additional aspects of cellular behavior, including metabolism, migration, differentiation and DNA repair.

Importantly, these diverse responses ultimately lead to common outcomes of affecting cell division, cell viability and cellular homeostasis, which all contribute to blocking tumorigenesis (Figure 4). For instance, by triggering metabolic changes and promoting DNA repair, p53 can indirectly affect cell division and cell survival. Canonical and non-canonical p53 responses thus integrate to produce these common outcomes to quell tumor development. p53-mediated tumor suppression thus likely reflects the combined effects of activation of numerous transcriptional programs and consequent regulation of various aspects of cellular behavior. The prevalence of TP53 mutations in cancer supports this hypothesis; as a TP53 mutation has profound effects on the cell, it allows many tumor-suppressive mechanisms to be simultaneously eliminated. In contrast, individual p53 target genes are not commonly found mutated, presumably because their mutation has more minimal effects than a TP53 mutation.

It remains a challenge to clearly elucidate the set of p53 target genes and downstream responses that contribute to tumor suppression. The list of such genes and responses is still growing, and the importance of only a small fraction has been interrogated in vivo. Furthermore, no single or combinatorial deletion of $\mathrm{p} 53$ target genes has recapitulated loss of p53 itself, and therefore strategies to assess the collaborative actions of many target genes and responses must be developed. Adding to the challenge is the fact that mechanisms critical for tumor suppression may be context dependent. Studying p53 responses in relevant cancer models, and in particular epithelial models that comprise the majority of human cancers, will be critical in future to highlight mechanisms fundamental for tumor suppression.

Unraveling the details of how p53 suppresses cancer is critical both for understanding tumor development and improving cancer treatment. By delineating pathways downstream of p53 that suppress cancer, we will establish more options and targets for therapeutic interventions. Restoring p53 function in human tumors has proven to be challenging, and targeting downstream pathways may be a more feasible option for attacking p53-mutant tumors. Further interrogation of p53 target genes and cellular responses in mouse models will illuminate how this powerful protein thwarts tumor development and ultimately lead to therapeutic advances.

\section{Conflict of Interest}

The authors declare no conflict of interest.
Acknowledgements. We thank Kathryn Bieging-Rolett and Brittany Flowers for critical reading of the manuscript. We apologize to those whose work we could not cite due to spatial constraints.

1. Vousden KH, Prives C. Blinded by the light: the growing complexity of p53. Cell 2009; 137 413-431.

2. Bieging KT, Mello SS, Attardi LD. Unravelling mechanisms of p53-mediated tumour suppression. Nat Rev Cancer 2014; 14: 359-370.

3. Olivier $M$, Hollstein $M$, Hainaut P. TP53 mutations in human cancers: origins, consequences, and clinical use. Cold Spring Harb Perspect Biol 2010; 2: a001008.

4. Donehower LA, Harvey M, Slagle BL, McArthur MJ, Montgomery CA Jr., Butel JS et al. Mice deficient for p53 are developmentally normal but susceptible to spontaneous tumours. Nature 1992; 356: 215-221.

5. Jacks T, Remington L, Williams BO, Schmitt EM, Halachmi S, Bronson RT et al. Tumor spectrum analysis in p53-mutant mice. Curr Biol 1994; 4: 1-7.

6. Malkin D, Li FP, Strong LC, Fraumeni JF Jr., Nelson CE, Kim DH et al. Germ line p53 mutations in a familial syndrome of breast cancer, sarcomas, and other neoplasms. Science 1990; 250: 1233-1238.

7. Schmitt CA, McCurrach ME, de Stanchina E, Wallace-Brodeur RR, Lowe SW. INK4a/ARF mutations accelerate lymphomagenesis and promote chemoresistance by disabling p53. Genes Dev 1999; 13: 2670-2677.

8. Eischen CM, Weber JD, Roussel MF, Sherr CJ, Cleveland JL. Disruption of the ARFMdm2-p53 tumor suppressor pathway in Myc-induced lymphomagenesis. Genes Dev 1999; 13: 2658-2669.

9. Jackson EL, Olive KP, Tuveson DA, Bronson R, Crowley D, Brown M et al. The differential effects of mutant p53 alleles on advanced murine lung cancer. Cancer Res 2005; 65 : 10280-10288.

10. Hingorani SR, Wang L, Multani AS, Combs C, Deramaudt TB, Hruban RH et al. Trp53R172H and KrasG12D cooperate to promote chromosomal instability and widely metastatic pancreatic ductal adenocarcinoma in mice. Cancer Cell 2005; 7: 469-483.

11. Kenzelmann Broz D, Attardi LD. In vivo analysis of $p 53$ tumor suppressor function using genetically engineered mouse models. Carcinogenesis 2010; 31: 1311-1318.

12. Giaccia AJ, Kastan MB. The complexity of p53 modulation: emerging patterns from divergent signals. Genes Dev 1998; 12: 2973-2983.

13. Horn HF, Vousden KH. Coping with stress: multiple ways to activate p53. Oncogene 2007; 26: $1306-1316$.

14. Hu W, Feng Z, Levine AJ. The regulation of multiple p53 stress responses is mediated through MDM2. Genes Cancer 2012; 3: 199-208.

15. Brady CA, Attardi LD. p53 at a glance. J Cell Sci 2010; 123(Pt 15): 2527-2532.

16. Olive KP, Tuveson DA, Ruhe ZC, Yin B, Willis NA, Bronson RT et al. Mutant p53 gain of function in two mouse models of Li-Fraumeni syndrome. Cell 2004; 119: 847-860.

17. Lang GA, Iwakuma T, Suh YA, Liu G, Rao VA, Parant JM et al. Gain of function of a p53 hot spot mutation in a mouse model of Li-Fraumeni syndrome. Cell 2004; 119: 861-872.

18. Brady CA, Jiang D, Mello SS, Johnson TM, Jarvis LA, Kozak MM et al. Distinct p53 transcriptional programs dictate acute DNA-damage responses and tumor suppression. Cell 2011; 145: 571-583.

19. Johnson TM, Hammond EM, Giaccia A, Attardi LD. The $\mathrm{p} 53 \mathrm{QS}$ transactivation-deficient mutant shows stress-specific apoptotic activity and induces embryonic lethality. Nat Genet 2005; 37: 145-152.

20. Candau R, Scolnick DM, Darpino P, Ying CY, Halazonetis TD, Berger SL. Two tandem and independent sub-activation domains in the amino terminus of p53 require the adaptor complex for activity. Oncogene 1997; 15: 807-816.

21. Venot C, Maratrat M, Sierra V, Conseiller E, Debussche L. Definition of a p53 transactivation function-deficient mutant and characterization of two independent p53 transactivation subdomains. Oncogene 1999; 18: 2405-2410.

22. Zhu J, Zhou W, Jiang J, Chen X. Identification of a novel p53 functional domain that is necessary for mediating apoptosis. J Biol Chem 1998; 273: 13030-13036.

23. Jiang D, Brady CA, Johnson TM, Lee EY, Park EJ, Scott MP et al. Full p53 transcriptional activation potential is dispensable for tumor suppression in diverse lineages. Proc Nat Acad Sci USA 2011; 108: 17123-17128.

24. Lane DP. Cancer. p53, guardian of the genome. Nature 1992; 358: 15-16.

25. Kastan MB, Onyekwere O, Sidransky D, Vogelstein B, Craig RW. Participation of p53 protein in the cellular response to DNA damage. Cancer Res 1991; 51(23 Pt 1): 6304-6311.

26. el-Deiry WS, Tokino T, Velculescu VE, Levy DB, Parsons R, Trent JM et al. WAF1, a potential mediator of p53 tumor suppression. Cell 1993; 75: 817-825.

27. Brugarolas J, Chandrasekaran C, Gordon JI, Beach D, Jacks T, Hannon GJ. Radiationinduced cell cycle arrest compromised by p21 deficiency. Nature 1995; 377: 552-557.

28. Deng C, Zhang P, Harper JW, Elledge SJ, Leder P. Mice lacking p21CIP1/WAF1 undergo normal development, but are defective in G1 checkpoint control. Cell 1995; 82. 675-684.

29. Doumont G, Martoriati A, Beekman C, Bogaerts S, Mee PJ, Bureau F et al. G1 checkpoint failure and increased tumor susceptibility in mice lacking the novel p53 target Ptprv. EMBO $J$ 2005; 24: 3093-3103.

30. Kastan MB, Zhan Q, el-Deiry WS, Carrier F, Jacks T, Walsh WV et al. A mammalian cell cycle checkpoint pathway utilizing p53 and GADD45 is defective in ataxia-telangiectasia. Cell 1992; 71: 587-597. 
31. Hollander MC, Sheikh MS, Bulavin DV, Lundgren K, Augeri-Henmueller L, Shehee R et al. Genomic instability in Gadd45a-deficient mice. Nat Genet 1999; 23: 176-184.

32. Lowe SW, Ruley HE, Jacks T, Housman DE. p53-dependent apoptosis modulates the cytotoxicity of anticancer agents. Cell 1993; 74: 957-967.

33. Lowe SW, Schmitt EM, Smith SW, Osborne BA, Jacks T. p53 is required for radiationinduced apoptosis in mouse thymocytes. Nature 1993; 362: 847-849.

34. Debbas M, White E. Wild-type p53 mediates apoptosis by E1A, which is inhibited by E1B Genes Dev 1993; 7: 546-554

35. Michalak EM, Jansen ES, Happo L, Cragg MS, Tai L, Smyth GK et al. Puma and to a lesser extent Noxa are suppressors of Myc-induced lymphomagenesis. Cell Death Differ 2009; 16: 684-696.

36. Fridman JS, Lowe SW. Control of apoptosis by p53. Oncogene 2003; 22: 9030-9040.

37. Martin-Caballero J, Flores JM, Garcia-Palencia P, Serrano M. Tumor susceptibility of p21 (Waf1/Cip1)-deficient mice. Cancer Res 2001; 61: 6234-6238.

38. Adnane J, Jackson RJ, Nicosia SV, Cantor AB, Pledger WJ, Sebti SM. Loss of p21WAF1/ CIP1 accelerates Ras oncogenesis in a transgenic/knockout mammary cancer model. Oncogene 2000; 19: 5338-5347.

39. Young NP, Crowley D, Jacks T. Uncoupling cancer mutations reveals critical timing of p53 loss in sarcomagenesis. Cancer Res 2011; 71: 4040-4047.

40. Tront JS, Hoffman B, Liebermann DA. Gadd45a suppresses Ras-driven mammary tumorigenesis by activation of c-Jun NH2-terminal kinase and p38 stress signaling resulting in apoptosis and senescence. Cancer Res 2006; 66: 8448-8454.

41. Hildesheim J, Bulavin DV, Anver MR, Alvord WG, Hollander MC, Vardanian L et al. Gadd45a protects against UV irradiation-induced skin tumors, and promotes apoptosis and stress signaling via MAPK and p53. Cancer Res 2002; 62: 7305-7315.

42. Liu G, Parant JM, Lang G, Chau P, Chavez-Reyes A, El-Naggar AK et al. Chromosome stability, in the absence of apoptosis, is critical for suppression of tumorigenesis in Trp53 mutant mice. Nat Genet 2004; 36: 63-68.

43. Timofeev O, Schlereth K, Wanzel M, Braun A, Nieswandt B, Pagenstecher A et al. p53 DNA binding cooperativity is essential for apoptosis and tumor suppression in vivo. Cell Rep 2013; 3: 1512-1525

44. Barboza JA, Liu G, Ju Z, El-Naggar AK, Lozano G. p21 delays tumor onset by preservation of chromosomal stability. Proc Natl Acad Sci USA 2006; 103: 19842-19847.

45. Artandi SE, DePinho RA. A critical role for telomeres in suppressing and facilitating carcinogenesis. Curr Opin Genet Dev 2000; 10: 39-46.

46. Cosme-Blanco W, Shen MF, Lazar AJ, Pathak S, Lozano G, Multani AS et al. Telomere dysfunction suppresses spontaneous tumorigenesis in vivo by initiating p53-dependent cellular senescence. EMBO Rep 2007; 8: 497-503.

47. Post SM, Quintas-Cardama A, Terzian T, Smith C, Eischen CM, Lozano G. p53-dependent senescence delays Emu-myc-induced B-cell lymphomagenesis. Oncogene 2010; 29: 1260-1269.

48. Dankort D, Filenova E, Collado M, Serrano M, Jones K, McMahon M. A new mouse mode to explore the initiation, progression, and therapy of BRAFV600E-induced lung tumors. Genes Dev 2007; 21: 379-384.

49. Collado M, Gil J, Efeyan A, Guerra C, Schuhmacher AJ, Barradas M et al. Tumour biology: senescence in premalignant tumours. Nature 2005; 436: 642 .

50. Chen Z, Trotman LC, Shaffer D, Lin HK, Dotan ZA, Niki M et al. Crucial role of p53dependent cellular senescence in suppression of Pten-deficient tumorigenesis. Nature 2005; 436: 725-730.

51. Symonds H, Krall L, Remington L, Saenz-Robles M, Lowe S, Jacks T et al. p53-dependent apoptosis suppresses tumor growth and progression in vivo. Cell 1994; 78: 703-711.

52. Yin C, Knudson CM, Korsmeyer SJ, Van Dyke T. Bax suppresses tumorigenesis and stimulates apoptosis in vivo. Nature 1997; 385: 637-640.

53. Lowe SW, Jacks T, Housman DE, Ruley HE. Abrogation of oncogene-associated apoptosis allows transformation of p53-deficient cells. Proc Natl Acad Sci USA 1994; 91: 2026-2030.

54. Schmitt CA, Fridman JS, Yang M, Baranov E, Hoffman RM, Lowe SW. Dissecting p53 tumor suppressor functions in vivo. Cancer Cell 2002; 1: 289-298.

55. Eischen CM, Roussel MF, Korsmeyer SJ, Cleveland JL. Bax loss impairs Myc-induced apoptosis and circumvents the selection of p53 mutations during Myc-mediated lymphomagenesis. Mol Cell Biol 2001; 21: 7653-7662.

56. Dansen TB, Whittield J, Rostker F, Brown-Swigart L, Evan Gl. Specific requirement for Bax not Bak, in Myc-induced apoptosis and tumor suppression in vivo. J Biol Chem 2006; 281 10890-10895.

57. Hemann MT, Zilfou JT, Zhao Z, Burgess DJ, Hannon GJ, Lowe SW. Suppression of tumorigenesis by the p53 target PUMA. Proc Natl Acad Sci USA 2004; 101: 9333-9338.

58. Beaudry VG, Jiang D, Dusek RL, Park EJ, Knezevich S, Ridd K et al. Loss of the p53/p63 regulated desmosomal protein Perp promotes tumorigenesis. PLoS Genet 2010; 6 : e1001168.

59. Bartkova J, Horejsi Z, Koed K, Kramer A, Tort F, Zieger $\mathrm{K}$ et al. DNA damage response as a candidate anti-cancer barrier in early human tumorigenesis. Nature 2005; 434: 864-870.

60. Gorgoulis VG, Vassiliou LV, Karakaidos P, Zacharatos P, Kotsinas A, Liloglou T et al. Activation of the DNA damage checkpoint and genomic instability in human precancerous lesions. Nature 2005; 434: 907-913.

61. Christophorou MA, Martin-Zanca D, Soucek L, Lawlor ER, Brown-Swigart L, Verschuren EW et al. Temporal dissection of p53 function in vitro and in vivo. Nat Genet 2005; 37 718-726.
62. Christophorou MA, Ringshausen I, Finch AJ, Swigart LB, Evan Gl. The pathological response to DNA damage does not contribute to p53-mediated tumour suppression. Nature 2006; 443: 214-217.

63. Hinkal G, Parikh N, Donehower LA. Timed somatic deletion of p53 in mice reveals ageassociated differences in tumor progression. PLOS ONE 2009; 4: e6654.

64. Efeyan A, Garcia-Cao I, Herranz D, Velasco-Miguel S, Serrano M. Tumour biology: policing of oncogene activity by p53. Nature 2006; 443: 159.

65. Li T, Kon N, Jiang L, Tan M, Ludwig T, Zhao Y et al. Tumor suppression in the absence of p53-mediated cell-cycle arrest, apoptosis, and senescence. Cell 2012; 149: 1269-1283.

66. Li T, Liu X, Jiang L, Manfredi J, Zha S, Gu W. Loss of p53-mediated cell-cycle arrest, senescence and apoptosis promotes genomic instability and premature aging. Oncotarget 2016; 7: 11838-11849.

67. Valente LJ, Gray DH, Michalak EM, Pinon-Hofbauer J, Egle A, Scott CL et al. p53 efficiently suppresses tumor development in the complete absence of its cell-cycle inhibitory and proapoptotic effectors p21, Puma, and Noxa. Cell Rep 2013; 3: 1339-1345.

68. Bieging-Rolett KT, Johnson TM, Brady CA, Beaudry VG, Pathak N, Han S et al. p19(Arf) is required for the cellular response to chronic DNA damage. Oncogene 2016; 35: 4414-4421.

69. Dixon SJ, Lemberg KM, Lamprecht MR, Skouta R, Zaitsev EM, Gleason CE et al. Ferroptosis: an iron-dependent form of nonapoptotic cell death. Cell 2012; 149: 1060-1072.

70. Dixon SJ, Stockwell BR. The role of iron and reactive oxygen species in cell death. Nat Chem Biol 2014; 10: 9-17.

71. Jiang L, Kon N, Li T, Wang SJ, Su T, Hibshoosh $\mathrm{H}$ et al. Ferroptosis as a p53-mediated activity during tumour suppression. Nature 2015; 520: 57-62.

72. Jennis M, Kung CP, Basu S, Budina-Kolomets A, Leu Jl, Khaku S et al. An African-specific polymorphism in the TP53 gene impairs p53 tumor suppressor function in a mouse model. Genes Dev 2016; 30: 918-930.

73. Ou Y, Wang SJ, Li D, Chu B, Gu W. Activation of SAT1 engages polyamine metabolism with p53-mediated ferroptotic responses. Proc Natl Acad Sci USA 2016; 113: E6806-E6812.

74. Wang SJ, Li D, Ou Y, Jiang L, Chen Y, Zhao Y et al. Acetylation is crucial for p53-mediated ferroptosis and tumor suppression. Cell Rep 2016; 17: 366-373.

75. Xie Y, Zhu S, Song X, Sun X, Fan Y, Liu J et al. The tumor suppressor p53 limits ferroptosis by blocking DPP4 activity. Cell Rep 2017; 20: 1692-1704.

76. Lin T, Chao C, Saito S, Mazur SJ, Murphy ME, Appella E et al. p53 induces differentiation of mouse embryonic stem cells by suppressing Nanog expression. Nat Cell Biol 2005; 7: 165-171.

77. Marion RM, Strati K, Li H, Murga M, Blanco R, Ortega S et al. A p53-mediated DNA damage response limits reprogramming to ensure iPS cell genomic integrity. Nature 2009; 460: 1149-1153.

78. Hanna J, Saha K, Pando B, van Zon J, Lengner CJ, Creyghton MP et al. Direct cell reprogramming is a stochastic process amenable to acceleration. Nature 2009; 462 : $595-601$.

79. Utikal J, Polo JM, Stadtfeld M, Maherali N, Kulalert W, Walsh RM et al. Immortalization eliminates a roadblock during cellular reprogramming into iPS cells. Nature 2009; 460: $1145-1148$.

80. Hong H, Takahashi K, Ichisaka T, Aoi T, Kanagawa O, Nakagawa M et al. Suppression of induced pluripotent stem cell generation by the p53-p21 pathway. Nature 2009; 460: $1132-1135$.

81. Kawamura T, Suzuki J, Wang YV, Menendez S, Morera LB, Raya A et al. Linking the p53 tumour suppressor pathway to somatic cell reprogramming. Nature 2009; 460: 1140-1144.

82. Choi YJ, Lin CP, Ho JJ, He X, Okada N, Bu P et al. miR-34 miRNAs provide a barrier for somatic cell reprogramming. Nat Cell Biol 2011; 13: 1353-1360.

83. Pant V, Quinas-Cardama A, Lozano G. The p53 pathway in hematopoesis: lessons from mouse models, implications for humans. Blood 2012; 120: 5118-5127.

84. Tao L, Roberts AL, Dunphy KA, Bigelow C, Yan H, Jerry DJ. Repression of mammary stem/ progenitor cells by p53 is mediated by Notch and separable from apoptotic activity. Stem Cells 2011; 29: 119-127.

85. McConnell AM, Yao C, Yeckes AR, Wang Y, Selvaggio AS, Tang $\mathrm{J}$ et al. p53 regulates progenitor cell quiescence and differentiation in the airway. Cell Rep 2016; 17: 2173-2182.

86. Zhao Z, Zuber J, Diaz-Flores E, Lintault L, Kogan SC, Shannon K et al. p53 loss promotes acute myeloid leukemia by enabling aberrant self-renewal. Genes Dev 2010; 24: 1389-1402.

87. Zheng $\mathrm{H}$, Ying $\mathrm{H}$, Yan $\mathrm{H}$, Kimmelman AC, Hiller DJ, Chen AJ et al. p53 and Pten control neural and glioma stem/progenitor cell renewal and differentiation. Nature 2008; 455: $1129-1133$.

88. Kruiswijk F, Labuschagne CF, Vousden KH. p53 in survival, death and metabolic health: a lifeguard with a licence to kill. Nat Rev Mol Cell Biol 2015; 16: 393-405.

89. Cheung EC, Athineos D, Lee $P$, Ridgway RA, Lambie W, Nixon $C$ et al. TIGAR is required for efficient intestinal regeneration and tumorigenesis. Dev Cell 2013; 25: 463-477.

90. Zaugg K, Yao Y, Reilly PT, Kannan K, Kiarash R, Mason J et al. Carnitine palmitoyltransferase $1 \mathrm{C}$ promotes cell survival and tumor growth under conditions of metabolic stress. Genes Dev 2011; 25: 1041-1051.

91. Jiang D, LaGory EL, Kenzelmann Broz D, Bieging KT, Brady CA, Link N et al. Analysis of p53 transactivation domain mutants reveals Acad11 as a metabolic target important for p53 pro-survival function. Cell Rep 2015; 10: 1096-1109.

92. Liou GY, Storz P. Reactive oxygen species in cancer. Free Radic Res 2010; 44: 479-496. 
93. Cano CE, Gommeaux J, Pietri S, Culcasi M, Garcia S, Seux M et al. Tumor protein 53induced nuclear protein 1 is a major mediator of p53 antioxidant function. Cancer Res 2009; 69: 219-226.

94. Al Saati T, Clerc P, Hanoun N, Peuget S, Lulka H, Gigoux V et al. Oxidative stress induced by inactivation of TP53INP1 cooperates with KrasG12D to initiate and promote pancreatic carcinogenesis in the murine pancreas. Am J Pathol 2013; 182 : 1996-2004.

95. Sablina AA, Budanov AV, llyinskaya GV, Agapova LS, Kravchenko JE, Chumakov PM. The antioxidant function of the p53 tumor suppressor. Nat Med 2005; 11: 1306-1313.

96. White $\mathrm{E}$. The role for autophagy in cancer. J Clin Invest 2015; 125: 42-46.

97. Kenzelmann Broz D, Spano Mello S, Bieging KT, Jiang D, Dusek RL, Brady CA et al. Global genomic profiling reveals an extensive p53-regulated autophagy program contributing to key p53 responses. Genes Dev 2013; 27: 1016-1031.

98. Rosenfeldt MT, O'Prey J, Morton JP, Nixon C, MacKay G, Mrowinska A et al. p53 status determines the role of autophagy in pancreatic tumour development. Nature 2013; 504: 296-300.

99. Rao S, Tortola L, Perlot T, Wirnsberger G, Novatchkova M, Nitsch R et al. A dual role for autophagy in a murine model of lung cancer. Nat Commun 2014; 5: 3056.

100. Strohecker AM, Guo JY, Karsli-Uzunbas G, Price SM, Chen GJ, Mathew R et al. Autophagy sustains mitochondrial glutamine metabolism and growth of Braf ${ }^{V 600 E}$-driven lung tumors. Cancer Discov 2013; 3: 1272-1285.

101. Hollander MC, Philburn RT, Patterson AD, Velasco-Miguel S, Friedberg EC, Linnoila Rl et al. Deletion of XPC leads to lung tumors in mice and is associated with early events in human lung carcinogenesis. Proc Natl Acad Sci USA 2005; 102 : 13200-13205.

102. Friedberg EC, Bond JP, Burns DK, Cheo DL, Greenblatt MS, Meira LB et al. Defective nucleotide excision repair in xpc mutant mice and its association with cancer predisposition. Mutat Res 2000; 459: 99-108.

103. Melis JP, Wijnhoven SW, Beems RB, Roodbergen M, van den Berg J, Moon H et al. Mouse models for xeroderma pigmentosum group $A$ and group $C$ show divergent cancer phenotypes. Cancer Res 2008; 68: 1347-1353.

104. Yoon T, Chakrabortty A, Franks R, Valli T, Kiyokawa H, Raychaudhuri P. Tumor-prone phenotype of the DDB2-deficient mice. Oncogene 2005; 24: 469-478.

105. Gordon DJ, Resio B, Pellman D. Causes and consequences of aneuploidy in cancer. Nat Rev Genet 2012; 13: 189-203.

106. Thompson SL, Compton DA. Proliferation of aneuploid human cells is limited by a p53dependent mechanism. J Cell Biol 2010; 188: 369-381.
107. Dudgeon $\mathrm{C}$, Chan $\mathrm{C}$, Kang W, Sun $\mathrm{Y}$, Emerson R, Robins $\mathrm{H}$ et al. The evolution of thymic lymphomas in p53 knockout mice. Genes Dev 2014; 28: 2613-2620.

108. Muller PA, Vousden $\mathrm{KH}$, Norman JC. p53 and its mutants in tumor cell migration and invasion. J Cell Biol 2011; 192: 209-218.

109. Kim NH, Kim HS, Li XY, Lee I, Choi HS, Kang SE et al. A p53/miRNA-34 axis regulates Snail1-dependent cancer cell epithelial-mesenchymal transition. J Cell Biol 2011; 195 417-433.

110. Chang CJ, Chao CH, Xia W, Yang JY, Xiong Y, Li CW et al. p53 regulates epithelialmesenchymal transition and stem cell properties through modulating miRNAs. Nat Cell Biol 2011; 13: 317-323.

111. Wang SP, Wang WL, Chang YL, Wu CT, Chao YC, Kao SH et al. p53 controls cancer cell invasion by inducing the MDM2-mediated degradation of Slug. Nat Cell Biol 2009; 11 : 694-704.

112. Caswell DR, Chuang $\mathrm{CH}$, Yang D, Chiou SH, Cheemalavagu S, Kim-Kiselak $\mathrm{C}$ et al. Obligate progression precedes lung adenocarcinoma dissemination. Cancer Discov 2014; 4: 781-789.

113. Dameron KM, Volpert OV, Tainsky MA, Bouck N. Control of angiogenesis in fibroblasts by p53 regulation of thrombospondin-1. Science 1994; 265: 1582-1584.

114. Xue W, Zender L, Miething C, Dickins RA, Hernando E, Krizhanovsky V et al. Senescence and tumour clearance is triggered by p53 restoration in murine liver carcinomas. Nature 2007; 445: 656-660.

115. Lujambio A, Akkari L, Simon J, Grace D, Tschaharganeh DF, Bolden JE et al. Non-cellautonomous tumor suppression by p53. Cell 2013; 153: 449-460.

116. Yoon KW, Byun S, Kwon E, Hwang SY, Chu K, Hiraki M et al. Control of signalingmediated clearance of apoptotic cells by the tumor suppress of p53. Science 2015; 349 : 1261669.

117. Kurose K, Gilley K, Matsumoto S, Watson PH, Zhou XP, Eng C. Frequent somatic mutations in PTEN and TP53 are mutually exclusive in the stroma of breast carcinomas. Nat Genet 2002; 32: 355-357.

118. Paterson RF, Ulbright TM, MacLennan GT, Zhang S, Pan CX, Sweeney CJ et al. Molecular genetic alterations in the laser-capture-microdissected stroma adjacent to bladder carcinoma. Cancer 2003; 98: 1830-1836.

119. Hill R, Song $Y$, Cardiff RD, Van Dyke T. Selective evolution of stromal mesenchyme with p53 loss in response to epithelial tumorigenesis. Cell 2005; 123: 1001-1011.

120. Kiaris H, Chatzistamou I, Trimis G, Frangou-Plemmenou M, Pafiti-Kondi A, Kalofoutis A. Evidence for nonautonomous effect of p53 tumor suppressor in carcinogenesis. Cancer Res 2005; 65: 1627-1630. 